\title{
The effect of international environmental institutions: how we might learn more
}

\author{
Thomas Bernauer
}

When is successful international collaboration possible? Can policymakers or other actors in international relations do something to facilitate cooperation, and if so, what? These questions, which are fundamental both to the study of international politics and the survival of humankind, raise two subquestions. First, under what conditions are states able to establish some form of cooperation? International institutions, which are sets of rules that may or may not involve international organizations, have received most attention in this regard. ${ }^{1}$ Second, can international institutions contribute to successful international collaboration, in some specific meaning of success, and if so, under what conditions? The second question is even more important than the first because it draws our attention to the form and quality of cooperation and to the possibilities of achieving welfare-increasing cooperation in the absence of supranational governance structures. Institutions are choice variables. If the degree of success in international collaboration can be influenced by the institutions we establish and operate, we can be more successful if we know how to design institutions that produce the desired effect.

The first subquestion has been treated extensively in the international

Earlier versions of this article were written during a stay at the Center for International Affairs, Harvard University, whose support I gratefully acknowledge. The research was supported by a grant from the Swiss National Fund for Scientific Research (grant 8220-30628). I thank the following persons for their advice and comments on various drafts: William Clark, Robert Friedheim, Philipp Hildebrand, Robert Keohane, Marc Levy, Martin List, Lisa Martin, Ronald Mitchell, John Odell, Dieter Ruloff, Detlef Sprinz, Arild Underdal, Michael Zürn, and the anonymous referees of International Organization. I also benefited from presentations of the paper in the International Institutions Seminar of Harvard's Center for International Affairs; the 1994 annual meeting of the International Studies Association in Washington, D.C.; and a round-table discussion at the Graduate Institute of International Studies in Geneva, Switzerland.

1. See, for example, Stephen D. Krasner, ed., Intemational Regimes (Ithaca, N.Y.: Cornell University Press, 1983); and Robert O. Keohane, "Institutionalist Theory and the Realist Challenge After the Cold War," working paper 92-7, Harvard University, Cambridge, Mass., Center for International Affairs, 1992.

International Organization 49, 2, Spring 1995, pp. 351-77

(1) 1995 by The IO Foundation and the Massachusetts Institute of Technology 
relations literature. ${ }^{2}$ Research on the second subquestion is still in its infancy, not least because it involves daunting evaluative and analytical problems. ${ }^{3}$ Every analyst who has tried knows that it is difficult to conceptualize and measure institutions as explanatory variables; do the same for the effect of institutions on behavior, the environment, or some other outcome; evaluate and measure the success or failure of institutions in some reliable and meaningful way; and develop and test theories to distinguish when and why different types of institutions are more successful.

This article claims that positive theorizing, based on rigorous empirical research, is still the most fruitful way of advancing our knowledge about the effect of institutions in international politics. It outlines a rational-choice-based research strategy that may serve as a starting point for future research. The focus is on international environmental institutions. Such institutions are here defined as sets of international regulations and organizations that were intentionally established by preexisting actors (states) through explicit, legally or politically binding, international agreements in order to regulate anthropogenic sources of negative externalities affecting the natural environment. ${ }^{4}$ However, many of the arguments are also relevant to the analysis of institutions in other areas of international relations.

2. See, for example, Kenneth A. Oye, ed., Cooperation Under Anarchy (Princeton, N.J.: Princeton University Press, 1986); Arthur A. Stein, Why Nations Cooperate: Circumstance and Choice in International Relations (Ithaca, N.Y.: Cornell University Press, 1990); and Oran R. Young, "The Politics of International Regime Formation: Managing Natural Resources and the Environment," International Organization 43 (Summer 1989), pp. 349-75.

3. Among the most important studies are Peter M. Haas, Robert O. Keohane, and Marc A. Levy, eds., Institutions for the Earth: Sources of Effective International Environmental Protection (Cambridge, Mass.: MIT Press, 1993); Oran R. Young, "The Effectiveness of International Institutions: Hard Cases and Critical Variables," in James N. Rosenau and Ernst-Otto Czempiel, eds., Govemance Without Government: Change and Order in World Politics (New York: Cambridge University Press, 1992), pp. 160-94; Jørgen Wettestad and Steinar Andresen, The Effectiveness of International Resource Cooperation: Some Preliminary Findings (Lysaker, Nonway: The Fridtjof Nansen Institute, 1991); Arild Underdal, "The Concept of Regime 'Effectiveness,' " Cooperation and Conflict 27 (September 1992), pp. 227-40; Marc A. Levy, "The Effectiveness of International Environmental Institutions: What We Think We Know, and How We Might Learn More," paper presented at the annual convention of the International Studies Association, Acapulco, Mexico, 23-27 March 1993); Marc Levy, Gail Osherenko, and Oran R. Young, The Effectiveness of International Regimes: A Design for Large-Scale Collaborative Research (Hanover, N.H.: Dartmouth College, Institute for Arctic Studies, 4 December 1991); and Jørgen Wettestad, Institutional Design and the Effectiveness of International Environmental Regimes: A Conceptual Framework (Lysaker, Norway: The Fridtjof Nansen Institute, 1994).

4. Somewhat broader definitions can be found in Martin List and Volker Rittberger, "Regime Theory and International Environmental Management," in Andrew Hurrell and Benedict Kingsbury, eds., The Intemational Politics of the Environment (Oxford: Clarendon Press, 1992), pp. 85-109; and Stephen D. Krasner, "Structural Causes and Regime Consequences: Regimes as Intervening Variables," in Krasner, International Regimes, p. 2. Note that the more narrow definition in this article controls for the peculiar (and poorly understood) effects that unintentionally established or informal institutions (often called social conventions) may have. For analyses of informal social institutions, see Jack Knight, Institutions and Social Conflict (Cambridge: Cambridge University Press, 1992); and Friedrich Kratochwil, "Contract and Regimes: Do IssueSpecificity and Variations of Formality Matter," in Volker Rittberger and Peter Mayer, eds., Regime Theory and International Relations (New York: Oxford University Press, 1993), pp. 73-93. 
International environmental cooperation has increased dramatically in the past two decades. Governments and their agents have responded to the growing array of national and transboundary ecological problems by negotiating, concluding, and modifying international treaties and other types of agreements and by establishing and reforming international organizations. ${ }^{5}$ International agreements are now in place for atmospheric ozone depletion, climate change, whaling, fisheries, marine pollution, river and lake management, transboundary air pollution, endangered species, trade in toxic waste, nuclear safety, deforestation, and many other issues. ${ }^{6}$

Like students of domestic politics, analysts of international relations know by intuition or practical experience that environmental institutions vary enormously in terms of their performance. Some institutions are little more than green window-dressing, whereas others achieve more than their creators had hoped for. To arrive at practical recommendations for the design and operation of institutions, however, we have to move beyond this conventional wisdom. We have to assess and compare institutional performance systematically and explain when and why specific types of institutions influence the behavior of governments, businesses, and other actors in a direction that solves the environmental problems that motivated their establishment.

The question about the effect of institutions is also at the center of a broader debate in international relations theory. The study of institutions has made an important comeback since the 1970 s. It has contributed significantly to the international cooperation literature by explaining when and why international institutions emerge or change. ${ }^{7}$ The advocates of this research program claim that institutions can facilitate the resolution of coordination and collaboration problems in international politics if they are properly designed and operated. ${ }^{8}$

5. Haas, Keohane, and Levy estimate that more than half of the 140 multilateral environmental treaties adopted since 1921 were concluded after the 1972 United Nations Conference on the Human Environment. See their Institutions for the Earth, p. 6.

6. See, for example, Lynton Keith Caldwell, International Environmental Policy: Emengence and Dimensions, 2d ed. (Durham, N.C.: Duke University Press, 1990); Andrew Hurrell and Benedict Kingsbury, eds., The International Politics of the Environment (Oxford: Clarendon Press, 1992); The Fridtjof Nansen Institute, Green Globe Yearbook 1993 (Oxford: Oxford University Press, 1993); Jessica Tuchman Mathews, ed., Preserving the Global Environment: The Challenge of Shared Leadership (New York: W. W. Norton, 1991); John E. Carroll, ed., International Environmental Diplomacy: The Management and Resolution of Transfrontier Environmental Problems (Cambridge: Cambridge University Press, 1988); and Dimitris Stevis, Valerie J. Assetto, and Stephen P. Mumme, "International Environmental Politics: A Theoretical Review of the Literature," in James P. Lester, ed., Environmental Politics and Policy: Theories and Evidence (Durham, N.C.: Duke University Press, 1989), pp. 289-313.

7. See, for example, Oran R. Young, International Cooperation: Building Regimes for Natural Resources and the Environment (Ithaca, N.Y.: Cornell University Press, 1989); Friedrich Kratochwil and John Gerard Ruggie, "International Organization: A State of the Art on an Art of the State," International Organization 40 (Autumn 1986), pp. 753-75; Krasner, International Regimes; Robert O. Keohane, International Institutions and State Power: Essays in International Relations Theory (Boulder, Colo.: Westview, 1989); and Rittberger and Mayer, Regime Theory and International Relations.

8. Robert Keohane, Michael McGinnis, and Elinor Ostrom, eds., Proceedings of a Conference on Linking Local and Global Commons, Held at Hanard University, April 23-25, 1992 (Cambridge, Mass.: Harvard University, The Center for International Affairs, 1993); and Haas, Keohane, and 
Thus they imply that policymakers and other actors in the international arena have some room for maneuver, delimited by power structures, national interests, and other nonchoice variables, for designing and operating institutions that increase the welfare of their participants.

The most basic assumption of this argument, that institutions can have an independent impact on behavior and other outcomes, has been persistently challenged by competing explanations of outcomes in international relations and particularly by neorealism. ${ }^{9}$ Proponents of realism argue that the design and effect of institutions simply reflect the existing distribution of power and national interests, and that collaboration falters quickly when these conditions change; powerful actors simply ignore or change international rules whenever they dislike them. Any correlations between institutions and outcomes that we may observe are spurious because both variables are driven by power and interests.

Empirical research, guided by a coherent theory and basic social science methodology, is the most productive way to assess these competing claims and arrive at insights that are of practical value to policymakers. Considerable amounts of data have been gathered on the design and operation of international environmental institutions, not least because of heightened concern about the environment around the time of the 1992 Earth Summit. These data and their as yet cursory analysis suggest that institutions may have an independent effect on progress in environmental protection under some circumstances. ${ }^{10} \mathrm{But}$, as the following section argues, the existing literature on the subject is quite weak from theoretical and methodological standpoints.

The subsequent section outlines a research strategy for measuring and explaining the effect of international environmental institutions more systematically. It submits that we can measure the outcomes to be explained in terms of goal attainment; that is, the difference over time or across cases between actor behavior-or the state of the natural environment-along dimensions identified by institutional goals and end points defined by institutional goals. We can

Levy, Institutions for the Earth. For a critical review of claims that institutions can facilitate progress in international politics, see Giulio M. Gallarotti, "The Limits of International Organization: Systematic Failure in the Management of International Relations," Intemational Organization 45 (Spring 1991), pp. 183-220.

9. See Stephen D. Krasner, "Structural Causes and Regime Consequences: Regimes as Intervening Variables," in Krasner, International Regimes, pp. 1-21; Emerson M. S. Niou and Peter C. Ordeshook, "Less Filling, Tastes Great: The Realist-Neoliberal Debate," World Politics 46 (January 1994), pp. 209-34; Robert Powell, "Anarchy in International Relations Theory: The Neorealist-Neoliberal Debate," International Organization 48 (Spring 1994), pp. 313-44; Stephen D. Krasner, "Global Communications and National Power: Life on the Pareto Frontier," World Politics 43 (April 1991), pp. 336-66; Kenneth N. Waltz, "The Emerging Structure of International Politics," Intemational Security 18 (Fall 1993), pp. 44-79; and David Baldwin, ed., Neorealism and Neoliberalism: The Contemporary Debate (New York: Columbia University Press, 1993).

10. See, for example, The Fridtjof Nansen Institute, Green Globe Yearbook 1993; Peter H. Sand, "Innovations in International Environmental Governance," Environment 32 (November 1990), pp. 16-44; and Peter H. Sand, ed., The Effectiveness of International Environmental Agreements: A Survey of Existing Legal Instruments (Cambridge: Grotius Publications, 1992). 
assess the effect of an institution in terms of the extent to which it contributes, ceteris paribus, to variation in goal attainment. We use these two variables to produce a score of institutional effectiveness. This score indicates the extent to which an institution has contributed to the resolution of the environmental problem that led to its establishment. Finally, we examine the implications of variation in institutional design for the effectiveness of institutions. Decisionmaking rules, membership and access conditions, and the compliance system of institutions are among the most important design dimensions.

The research strategy proposed in this article provides a starting point for more rigorous and comparable case studies. Such studies are necessary to fine tune the research strategy and generate new hypotheses about the impact of variation in institutional design. The research strategy outlined here also can serve as a starting point for larger scale comparative work. Without such work, we cannot arrive at comparable assessments and generalizable explanations of the effect and effectiveness of international institutions.

\section{Weaknesses of current research}

Current research on the effect of international environmental institutions suffers from two types of weaknesses. The first is confusion about the dependent variable. Broadly conceived, this variable expresses the extent to which institutions contribute to resolving international environmental problems. Second, most authors define their explanatory variables, particularly international institutions, vaguely. In addition, analysts have focused predominantly on whether the existence or operation of institutions per se has an effect on progress in environmental problem solving. They have not produced generalizable answers as to what types of institutions are more successful than others under specific conditions; that is, which dimensions of institutional design are crucial to institutional success or failure.

\section{The dependent variable}

The concept of institutional effect raises three questions. Which outcomes do institutions affect and which of these outcomes should analysts focus on? How can these outcomes be evaluated in terms of institutional success or failure? Which measurement operations are required to assess the effect of an institution?

In principle, international environmental institutions can be said to have an effect if they influence any type of outcome. We may argue that international regulations on atmospheric ozone depletion have an effect if a single firm reduces its production of chlorofluorocarbons (CFCs), substances that contribute to the destruction of the ozone layer. The same regulations may also 
decrease, say, a government's incentive to promote the domestic production of CFCs. ${ }^{11}$ In the first case, the outcome to explain is the behavior of firms. In the second case, it is the interests or behavior of governments. The list of possible outcomes is long. Michael Zürn, for example, distinguishes among fifteen groups of variables that institutions may affect. This typology is defined by level of analysis (government, society/domestic politics, issue area) and the behavior, capabilities, cognition, values and interests, and constitution of the units at the different levels of analysis. ${ }^{12}$

Because the chances of finding significant causal relationships decline rapidly with the number of dependent variables, any research design will have to focus on a single or very few outcomes that can be measured reliably and that are valid in the sense of capturing the "true" meaning of institutional effect. But analysts disagree about which outcomes are relevant from a theoretical or normative perspective and which outcomes can be analyzed from a methodological standpoint (e.g., is there enough variance to explain, are sufficient data available in accessible form, can outcomes be aggregated). To make matters worse, most studies define their dependent variable(s) vaguely. As a result, they operate with ill-defined analytical frameworks, which produces results that do not systematically flow from the empirical data and are rarely comparable.

The authors of Institutions for the Earth, one of the most influential studies on the effect of international environmental institutions, refer almost interchangeably to institutional effect, impact, effectiveness, institutional roles or functions, success or failure, and compliance, as well as to actor behavior and the state of the natural environment as the outcome to be explained. At other points, they argue that they explain the impact of institutions on environmental concern, on the international contractual environment, and on domestic capacity for environmental protection at three stages in the environmental protection process: agenda setting, bargaining and contracting, and implementation. ${ }^{13}$ The place of these variables, or rather concepts, in the analytical framework of the project remains unclear. They appear both as explanations for the success or failure of environmental protection and as dependent variables that are influenced by institutions and exogenous variables such as power and interests. Hence, it seems that they are regarded both as causes and consequences of international institutions. In addition, the relationships among these concepts and behavioral and environmental outcomes remain largely hypothetical.

11. For an analysis of the stratospheric ozone case, see Richard E. Benedick, Ozone Diplomacy: New Directions in Safeguarding the Planet (Cambridge, Mass.: Harvard University Press, 1991).

12. Michael Zürn, "Consequences of Regime Definitions and Definitions of Regime Consequences: Proposals for a Data Bank on International Regimes," working paper, presented at a meeting entitled "Regimes Summit," Institute of Arctic Studies, Dartmouth College, Hanover, New Hampshire, October 1991.

13. Haas, Keohane, and Levy, Institutions for the Earth, pp. 3-24 and 397-426. 
Harold Jacobson and David Kay, in one of the pioneering studies on the effect of international environmental organizations, use multiple indicators: for example, participant and observer attitudes toward accomplished results, procedural and substantial goal attainment, and the impact of a program on the environment. ${ }^{14} \mathrm{~A}$ research design with so many dependent variables, which are difficult to aggregate, and that compares only eleven cases does not permit generalizable causal claims about the effect of international environmental organizations. In a study on international trade in textiles, Vinod Aggarwal explains regime strength, defined as the "stringency with which rules regulate the behavior of countries." 15 The validity of this variable is based on the assumption that more concrete and binding regulations are more likely to have an impact on actor behavior. This assumption blurs the distinction of institutions as explanatory and actor behavior as dependent variables and renders the analysis of institutional effect very difficult. Elinor Ostrom, who examines the management of common pool resources at the domestic level, explains a mixture of regulatory output and implementation of regulations. She defines the failure of institutions as not being able to put a regime in place or having a set of rules that are not enforced. ${ }^{16}$ This definition lumps together the explanation of cooperation as such and the explanation of institutional performance. On a more abstract level, authors such as Marc Levy and Arild Underdal seem to disagree over whether social scientists should explain behavior or changes in the natural environment. ${ }^{17}$

The next point to clarify concerns evaluative criteria. Such criteria are required to measure and compare the extent and direction of an institutional effect on a given outcome. We are interested in whether, and to what degree, institutions drive outcomes in a "good" or "bad" direction. For example, Levy notes that because the International Whaling Commission established global but not national quotas, it generated a whaling olympic. National fishing industries acquired large fishing fleets that were economically efficient only if they killed whales at an ecologically unsustainable rate. ${ }^{18}$ In this case, the

14. Harold K. Jacobson and David A. Kay, eds., Environmental Protection: The International Dimension (Totowa, N.J.: Allanheld/Osmun, 1983).

15. Vinod K. Aggarwal, Liberal Protectionism: The Intemational Politics of Organized Textile Trade (Berkeley: University of California Press, 1985), p. 20. Similar concepts can be found in Mark V. Zacker, "Trade Gaps, Analytical Gaps: Regime Analysis and International Commodity Trade Regulation," International Organization 41 (Spring 1987), p. 117; and Abram Chayes and Antonia Handler Chayes, "Compliance Without Enforcement: State Behavior Under Regulatory Treaties," Negotiation Journal (July 1991), pp. 311-30.

16. Elinor Ostrom, Governing the Commons: The Evolution of Institutions for Collective Action (Cambridge: Cambridge University Press, 1990), pp. 55-56.

17. See Levy, The Effectiveness of International Environmental Institutions; and Underdal, "The Concept of Regime 'Effectiveness.'"

18. Levy, The Effectiveness of International Environmental Institutions, p. 4. On the whaling case, see M. J. Peterson, "Whalers, Cetologists, Environmentalists, and the International Management of Whaling," Intemational Organization 46 (Winter 1992), pp. 147-86; and Halldor Asgrimsson, "Developments Leading to the 1982 Decision of the International Whaling Commission for a Zero Catch Quota 1986-90," in Steinar Andresen and Willy Østreng, International Resource Manage- 
whaling institution would be successful to the degree that it succeeds in keeping whale stocks at a sustainable level.

Besides disagreeing over the outcomes to be explained, analysts also disagree about the standards against which these outcomes should be evaluated. Successful institutions, in a very comprehensive sense of success, are those that (1) change the behavior of states and other actors in the direction intended by the cooperating parties, (2) solve the environmental problems they are supposed to solve, and (3) do so in an efficient and equitable manner..$^{19}$ No study has tried to evaluate outcomes, however defined, against all three criteria, and any effort to do so is bound to fail due to the extreme complexity of the task. Even the evaluation against more narrowly defined standards poses great difficulties.

Elsewhere, I have tried to assess the efficiency of regulations concerning pollution of the river Rhine. ${ }^{20} \mathrm{I}$ argue that the high transaction costs of negotiating and implementing chloride reductions along the Rhine through international financing of such reductions at a potash mine in France have all but eliminated the efficiency gains of this approach as compared with alternative approaches. The evaluation of efficiency involves assessing the costs and benefits of establishing and operating an environmental institution and then comparing these costs and benefits to those of alternative behavioral options. The standard for efficiency is usually the Pareto frontier. At this point, no actor can achieve a greater benefit without making at least one other actor worse off. Efficiency tends to be a more attractive concept for abstract reasoning than for empirical research. ${ }^{21}$ Costs and benefits in environmental politics, which determine the utility functions of the actors, are often nonmonetary and difficult to measure unless we take the problematic step of inferring ex ante preferences from observed behavior. ${ }^{22}$ In addition, as Underdal notes, the Pareto frontier is very sensitive to changes in the set of actors, preferences, and issues. ${ }^{23}$ Comparing efficiency across cases and time is thus very difficult, and most efficiency assessments, such as in the Rhine case, remain extremely crude.

Zürn examines the conditions under which institutions that are just emerge. ${ }^{24}$

ment: The Role of Science and Politics (London: Belhaven Press, 1989), pp. 221-31. Negative effects of international institutions are discussed by Gallarotti, "The Limits of International Organization."

19. For a discussion of various evaluative standards, see Young, "The Effectiveness of International Institutions"; and Underdal, "The Concept of Regime 'Effectiveness." "

20. Thomas Bernauer, "International Financing of Environmental Protection: Lessons from Efforts to Protect the River Rhine Against Chloride Pollution," Environmental Politics, forthcoming.

21. For an abstract comparison of five global regimes for greenhouse gas reductions against economic efficiency criteria, see Joshua M. Epstein and Raj Gupta, Controlling the Greenhouse Effect: Five Global Regimes Compared (Washington, D.C.: Brookings Institution, 1990).

22. Frances Cairncross, Costing the Earth (London: Economist Books, 1991).

23. Underdal, "The Concept of Regime 'Effectiveness," " pp. 230-34.

24. Michael Zürn, Gerechte Internationale Regime: Bedingungen und Restriktionen der 
The assessment of justice, which in this case is closely related to equity, involves the evaluation of the distribution of costs and benefits that flow from international interaction and a comparison of this distribution against some normatively preferred distribution. This evaluative criterion is even more problematic than the efficiency standard. Besides the problem of measuring costs and benefits, any assessment of equity or justice has to be based on a theory of fairness; and virtually all theories of equity or fairness are controversial. ${ }^{25}$

Several authors have proposed simpler evaluative criteria. Many of them, for example Abram Chayes, Antonia Handler Chayes, and Ronald Mitchell, examine compliance. Compliance may be defined as the degree to which actor behavior conforms to the injunctions set by the rules of an institution. ${ }^{26}$ The use of this criterion creates an endogeneity problem: the evaluative standard that is used in the measurement of the dependent variable (behavior is assessed against rules) is also part of the explanatory concept (institutions include the same rules). This problem renders causal inference regarding the effect of institutions on outcomes very difficult. With few exceptions, such as Mitchell's study on oil pollution, compliance with institutional rules rarely has been traced back to institutions in a systematic manner. ${ }^{27}$ In addition, compliance may not tell us much about the success of an institution in solving the environmental problem that motivated its establishment. International rules can be designed so that even the worst polluters easily comply without having to change their behavior significantly.

Jørgen Wettestad and Steinar Andresen propose three evaluative criteria, two of which avoid the pitfalls of the compliance concept: the degree to which the parties have reached the institutional goals; the degree to which expert advice and actual decisions correlate; and the degree to which the state of the environment has improved as compared with what would have happened in the absence of the institution..$^{28}$ The first criterion is broader than compliance but also creates the same endogeneity problem. The second criterion reflects an

Entstehung nicht-hegemonialer internationaler Regime untersucht am Beispiel der Weltkommunikationsordnung (Just international regimes: Conditions and restrictions for the emergence of nonhegemonic international regimes, analyzed on the basis of the world communication order) (Frankfurt a.M: Haag und Herchen, 1987).

25. For a rational-choice-based analysis of equity and fairness issues, see Peyton H. Young, Equity in Theory and Practice (Princeton, N.J.: Princeton University Press, 1994).

26. See Abram Chayes and Antonia Handler Chayes, "On Compliance," International Organization 47 (Spring 1993), pp. 175-205; Ronald B. Mitchell, Intentional Oil Pollution at Sea: Environmental Policy and Treaty Compliance (Cambridge, Mass.: MIT Press, 1994); and Oran R. Young, Compliance and Public Authority: A Theory with International Applications (Baltimore, Md.: Johns Hopkins University Press, 1979); and Stephen Haggard and Beth A. Simmons, "Theories of International Regimes," International Organization 41 (Summer 1987), pp. 491-517 and p. 496 in particular.

27. Mitchell, Intentional Oil Pollution at Sea.

28. Wettestad and Andresen, The Effectiveness of International Resource Cooperation. 
attempt to control for whether institutional goals are conducive to environmental protection. Hence it is more valid than compliance in terms of capturing the "true" meaning of institutional success. Its principal problem is that scientists often disagree or their advice may be wrong. The third criterion evaluates relative progress in environmental protection against the baseline of a world without the institution. This criterion includes a counterfactual component that introduces an element of more or less informed speculation into the measurement of the dependent variable.

Marc Levy, Gail Osherenko, and Oran Young focus on the behavior of members of an institution in accordance with the broader objectives the institution was established to achieve. ${ }^{29}$ This concept is attractive from the validity viewpoint because it relates to problem solving. The endogeneity problem is smaller because broad institutional goals are usually not as closely related to institutional design and operation as specific rules or more narrowly defined goals. In addition, this criterion does not require the agreement of scientists or counterfactual assessment. The institution regulating chloride pollution of the Rhine can, for example, be evaluated in terms of the evolution of chloride concentrations with regard to the goal of eliminating the damage that chloride pollution inflicts on Dutch farmers and waterworks.

Two problems, however, with the criterion of problem solving remain. First, it is difficult to weigh the observed outcome against the environmental problem and to compare this assessment across cases. Large changes of behavior in the desired direction for the area of stratospheric ozone depletion may constitute a much smaller success than small changes of behavior on a much bigger problem, such as global warming. ${ }^{30}$ Second, if an institution has more than one goal, we face problems of aggregation. In the case of international regulations on whaling before 1982, it will be difficult to aggregate the welfare of the whaling industry with some notion of sustainable whale stocks. The international institution overseeing chemical pollution of the Rhine has had more success in establishing an early warning system for accidental spills than in actually cleaning up the Rhine.

The third problem in defining and measuring the dependent variable stems from the causal element inherent in the concept of institutional effect. Most studies ignore this causal element. They assess changes of behavior, the natural environment, or other outcomes in the issue-area covered by an institution. If change is observed, it is attributed to the institution, based on some sketchy theoretical or empirical argument. Charlotte $\mathrm{Ku}$, for example, argues that the law of the sea convention has had the effect of spurring the settlement of boundary disputes. She notes that of the more than 130 ocean boundaries that were regarded as settled in $1989,60-65$ percent were settled after it became

29. Levy, Osherenko, and Young, The Effectiveness of International Regimes.

30. Underdal, "The Concept of Regime 'Effectiveness," "p. 229. 
evident that the Third United Nations Conference on the Law of the Sea would formally recognize multiple bands of coastal state jurisdiction. ${ }^{31}$

Such assessments of institutional effect are deficient because they do not control the impact of exogenous variables on the observed correlation between institutions and outcomes. The increase in the settlement of boundary disputes in the law of the sea case might, for example, have been caused by the general growth in maritime traffic or other uses of the sea, irrespective of the international regulatory effort. Conversely, we may misinterpret as a failure a case where marine pollution did not improve following the creation of a new institution because a noninstitutional factor neutralized the positive effect of the institution. An increased pollution input from a nonregulated source, such as a tributary river, may have such an effect.

Some authors try to control exogenous variables but fail to do so rigorously because they do not distinguish between institutional and noninstitutional variables clearly enough. Peter Haas, in his study of institutions to protect regional seas, employs exogenous explanatory factors that are largely identical to the United Nations Environment Program's institutional objectives. ${ }^{32}$ Wettestad and Andresen distinguish two types of explanatory variables: problem solving and capacity of a regime. It seems, however, that both categories include institutional as well as power- and interest-related variables. ${ }^{33}$

The theoretical value of studies that do not sufficiently control exogenous variables is small because they ignore critics who argue that institutions are merely frozen interests and power structures and do not have an independent effect on outcomes in international affairs. These critics claim that when we observe that states behave in accordance with institutional rules or goals, these states do not comply because the designers of the institution made smart choices. They comply because powerful states threaten potential violators with economic sanctions or because compliance is so beneficial that states would comply irrespective of what other actors do.

\section{Institutional design}

Analysts have focused on whether the existence or operation of institutions per se has an effect on particular outcomes rather than on specific institutional features that may account for variation in institutional effect. Projects led by Haas, Keohane, and Levy, and by Levy, Osherenko, and Young, for example, are based on the inductive analysis of the functions through which institutions

31. Charlotte Ku, "Ocean Boundaries: Does the 1982 Law of the Sea Convention Matter?" paper prepared for the annual convention of the International Studies Association in Acapulco, Mexico, 23-27 March 1993.

32. Peter M. Haas, Saving the Mediterranean: The Politics of International Environmental Cooperation (New York: Columbia University Press, 1990).

33. Wettestad and Andresen, The Effectiveness of International Resource Cooperation. 
may contribute to progress in environmental protection. The suggested functions are roughly compatible with the behavioral models that can be found in the sociologically oriented and rational-choice literature. ${ }^{34}$

This approach tells us how institutions may influence outcomes by shaping behavior in a variety of ways. It also makes an attempt to control the influence of noninstitutional variables. But it does not explain in a generalizable way the degree of institutional success or failure in terms of variation in the features of institutions. Not surprisingly, therefore, the advice that policymakers may derive from these studies remains vague or idiosyncratic. It consists of information on how policymakers have, in the cases examined, dealt with environmental problems through international institutions and how these institutions have contributed, each one in its peculiar way, to success or failure in environmental management ${ }^{35}$ It is up to individual policymakers to evaluate whether the insights from a given case are applicable to other cases.

There is no shortage of suggestions as to which dimensions of institutional design are potentially relevant to the performance of international environmental institutions. (I henceforth use the term "institutional design" in a sense that includes constitutional design variables and operational factors.) Young highlights transparency procedures, collective choice mechanisms, and transformation rules. ${ }^{36}$ The Chayeses and Mitchell stress the importance of monitoring. ${ }^{37}$ Peter Sand argues that the following institutional design features make international environmental protection more effective: interim operation of environmental treaties before entry into force; utilization of soft law; regulations applied to the regional rather than global level; differential instead of universally applicable obligations; delegation of decision-making authority to specialized organs; regular reviews of the operation of treaties; and selective incentives..$^{38}$ Andresen and Wettestad emphasize the number of actors and the

34. For examples of the former, see James N. Rosenau, "Before Cooperation: Hegemons, Regimes, and Habit-Driven Actors in World Politics," International Organization 40 (Autumn 1986), pp. 849-94; Friedrich V. Kratochwil, "The Force of Prescriptions," International Organization 38 (Autumn 1984), pp. 685-708; Friedrich V. Kratochwil, Rules, Norms, and Decisions: On the Conditions of Practical and Legal Reasoning in International Relations and Domestic Affairs (Cambridge: Cambridge University Press, 1991); Alexander Wendt, "Anarchy is What States Make of it: The Social Construction of Power Politics," Intemational Organization 46 (Spring 1992), pp. 391-425; and Alexander Wendt and Raymond Duvall, "Institutions and International Order," in Ernst-Otto Czempiel and James N. Rosenau, eds., Global Changes and Theoretical Challenges: Approaches to World Politics for the 1990s (Lexington, Mass.: Lexington Books, 1989), pp. 51-73. For examples of the latter, see Knight, Institutions and Social Conflict; Beth V. Yarbrough and Robert M. Yarbrough, "International Institutions and the New Economics of Organization," International Organization 44 (Spring 1990), pp. 235-59; Oliver E. Williamson, The Economic Institutions of Capitalism: Firms, Markets, Relational Contracting (New York: Free Press, 1985); Robert O. Keohane, "The Demand for International Regimes," in Krasner, International Regimes, pp. 141-71; and Robert O. Keohane, After Hegemony: Cooperation and Discord in the World Political Economy (Princeton, N.J.: Princeton University Press, 1984).

35. See in particular Haas, Keohane, and Levy, Institutions for the Earth, pp. 408-15.

36. Young, "The Effectiveness of International Institutions."

37. See Chayes and Chayes, "On Compliance"; and Mitchell, Intentional Oil Pollution at Sea.

38. See Peter H. Sand, Lessons Learned in Global Environmental Governance (Washington, D.C.: 
scope of the institutional agenda. ${ }^{39}$ Wettestad stresses the importance of participatory scope and access to an institution, decision-making rules, the role of secretariats, the scope of the institutional agenda, the organization of scientific or technical input, and verification and compliance mechanisms..$^{40}$ Most of these propositions are not embedded in a coherent theoretical argument. They are ad hoc hypotheses derived from intuition, inductive studies, a large spectrum of social science theories, and practical knowledge on the conduct of international environmental politics. Further, they have not been systematically tested and compared in terms of their relative explanatory weight.

The most rigorous research on the implications of variation in institutional design has been carried out by students of institutions at the domestic level. It has examined general design principles that underlie successful, self-organized institutions for the management of common pool resources, such as fisheries, communal forests and grazing areas, groundwater basins, oil fields, or irrigation systems ${ }^{41}$ Michael McGinnis and Elinor Ostrom, for example, argue that the following design principles make local common pool resource institutions more successful and project these insights to the international level: clearly defined boundaries of a resource and the right to use the resource; congruence among rules and local conditions; involvement of individuals affected by the rules in rule modification; monitoring by the users of the resource or by agents accountable to the users; the same for sanctions, which should be graduated; access to low-cost conflict resolution mechanisms; a certain autonomy of local institutions from higher authorities; and the organization of institutions in nested layers. ${ }^{42}$

The extent to which these propositions are relevant to environmental institutions at the international level is largely an open question. Some propositions might be irrelevant. Haas, Keohane, and Levy, the Chayeses, and

World Resources Institute, 1990); and Peter H. Sand, "Innovations in International Environmental Governance."

39. Wettestad and Andresen, The Effectiveness of International Resource Cooperation.

40. See also Wettestad, Institutional Design and the Effectiveness of International Environmental Regimes. For an analysis of the science and politics interface in international environmental affairs, see Andresen and Østreng, Intemational Resource Management; Tora Skodvin and Arild Underdal, "The Science-Politics Interface: Transforming Knowledge into Decision Inputs for International Environmental Regimes," paper presented at the annual meeting of the International Studies Association, Washington, D.C., 29 March-1 April 1994; and Michael E. Kowalok, "Research Lessons from Acid Rain, Ozone Depletion, and Global Warming," Environment 35 (July/August 1993), pp. 12-38.

41. Keohane, McGinnis, and Ostrom, Proceedings of a Conference on Linking Local and Global Commons; and Ostrom, Governing the Commons. Another area of research on institutions at the domestic level deals with legislatures. See, for example, Kenneth A. Shepsle and Barry R. Weingast, "The Institutional Foundations of Committee Power," American Political Science Review 81 (March 1987), pp. 85-104.

42. See Michael McGinnis and Elinor Ostrom, "Design Principles for Local and Global Commons," in Keohane, McGinnis, and Ostrom, Proceedings of a Conference on Linking Local and Global Commons, pp. 16-65; and Ostrom, Governing the Commons, p. 90. 
others claim that sanctions play only a minor role in affecting the behavior of actors in international environmental politics. ${ }^{43}$ The proposition concerning the autonomy of local institutions from higher authorities is rarely applicable in international affairs. With the exception of the European Union (EU), there is no higher authority. In addition, the explanatory value of these propositions for domestic-level institutions remains contested. Michael Taylor, for example, notes that they are not linked to a coherent explanatory theory and are based on a very informal analytical framework. He also argues that the proposed design principles appear to be features or results rather than causes of successful resolution of common pool resource problems. ${ }^{44}$

\section{How we might learn more}

The remainder of this article outlines a research strategy in three steps to evaluate the effect of institutions per se and to explain variation in the effectiveness of institutions in terms of their design. First, the outcome to be explained is measured in terms of goal attainment. Goal attainment is defined as the difference, over time or across cases, between actor behavior or the state of the natural environment along dimensions identified by institutional goals, on the one hand, and certain endpoints defined by institutional goals, on the other. Second, the effect of an institution is measured in terms of the extent to which the existence or operation of the institution contributes, ceteris paribus, to variation in goal attainment. These two variables are transformed into a score of institutional effectiveness. This score indicates the degree to which an institution has contributed to the resolution of the environmental problem that motivated its establishment. Third, the effect of variation along specific dimensions of institutional design (such as decision-making rules, membership and access conditions, and the compliance system) is analyzed.

The basic assumptions underlying the proposed research strategy are those of rational-choice theory. I assume states to be unitary and boundedly rational actors. Cooperation between these actors is often difficult because the costs and benefits of behavioral options as well as the preferences and behavior of other actors are uncertain, the actors are opportunistic, and enforcement is imperfect and costly. Under these circumstances, international institutions facilitate cooperation by signaling the parties' commitment to an ongoing relationship, hence lengthening the shadow of the future. They generate information, thus increasing transparency, reducing uncertainty, and facilitat-

43. See Haas, Keohane, and Levy, Institutions for the Earth; and Chayes and Chayes, "Compliance Without Enforcement."

44. Michael Taylor, "The Economics and Politics of Property Rights and Common Pool Resources," Natural Resources Journal 32 (Summer 1992), p. 640 in particular. 
ing strategies of reciprocity. They help to mediate disputes and provide procedures for aggregating individual choices at lower (transaction) cost. ${ }^{45}$

Some versions of this argument claim that institutions are efficient solutions to collective action problems. Institutions exist because they are instrumental in maximizing states' utility. If they do not perform well, they will disappear. In this Darwinist view of institutions, the study of institutional effect is uninteresting. There will be little variation in the performance of existing institutions, which are those that have survived the selection process because they are efficient.

To escape this tautological argument, Jon Elster has demanded a stringent assessment of functional theories. Analysts must show that an institution serves an unintended and unrecognized function for a group of actors and that this function feeds back to maintain or reproduce the institution. ${ }^{46}$ Herbert Simon has suggested a less demanding requirement. He states that "Institutions are functional if reasonable men might create and maintain them in order to meet social needs or achieve social goals." 47 This argument does not require demonstration of unintended or unrecognized functions. Nor does it imply that only efficient institutions survive. It allows for variation in the performance of existing institutions.

Analysts have used two research strategies to demonstrate that institutions, through the functions they perform, are responsible for some variation in collective outcomes. The first strategy, exemplified by Haas, Keohane, and Levy, and by Levy, Osherenko, and Young, constructs detailed narrative accounts that trace causal pathways from institutions to outcomes. ${ }^{48}$ It seeks to demonstrate that institutions affect collective outcomes by performing the functions proposed by rational-choice theory or some other behavioral model. The second approach, used by McGinnis and Ostrom, and by Wettestad and Andresen, develops hypotheses that link explanatory variables to collective outcomes. ${ }^{49}$ It then identifies and measures variation in the existence and operation of institutions, specific dimensions of institutional design, collective outcomes, and institutional performance and examines whether these variables correlate over time or across cases. Controlling exogenous variables, advancing theoretical arguments about the relevance of explanatory variables to the

45. See Yarbrough and Yarbrough, "International Institutions and the New Economics of Organization"; and Andrew Kydd and Duncan Snidal, "Progress in Game-Theoretical Analysis of International Regimes," in Rittberger and Mayer, Regime Theory and International Relations, pp. $112-35$.

46. Jon Elster, Explaining Technical Change: $A$ Case Study in the Philosophy of Science (Cambridge: Cambridge University Press, 1983).

47. Herbert Simon, "Rationality as Process and as Product of Thought," American Economic Review Papers and Proceedings 68 (May 1978), p. 3.

48. See Haas, Keohane, and Levy, Institutions for the Earth; and Levy, Osherenko, and Young, The Effectiveness of International Regimes.

49. See McGinnis and Ostrom, "Design Principles for Local and Global Commons"; Wettestad and Andresen, The Effectiveness of International Resource Cooperation; and Wettestad, Institutional Design and the Effectiveness of Intemational Environmental Regimes. 
performance of institutional functions, and the (usually sketchy) empirical tracing of causal pathways bolster claims that correlations reflect causal relationships.

The research strategy proposed below reflects the second approach. This approach is preferable because it facilitates comparative research, which is indispensable for arriving at more generalizable propositions about necessary or sufficient conditions for the effect or effectiveness of institutions. As noted earlier, the first approach alone cannot generate such knowledge. I will argue, however, that the first research strategy can support the second.

\section{Measuring outcomes}

Outcomes to be explained should, first, be closely related to problem solving and second, reliably measured. As Yarbrough and Yarbrough note, problem solving is the dominant idea in rational-choice-based institutionalism, which emphasizes the purposive, intentional, and instrumental character of social institutions. ${ }^{50}$ We are ultimately concerned more about cleaner rivers, sustainable fisheries, or lower greenhouse gas emissions and less about political popularity functions or treaty ratifications. Outcomes associated more indirectly with institutions may, nonetheless, be important. Institutions can have a positive spillover effect on cooperative efforts in other issue-areas, or they may have a general effect on confidence and conflict resolution (as in the case of some East-West environmental institutions-for example, the one for the Barents Sea) ${ }^{51}$ But such outcomes are harder to trace back to institutions because causal chains are likely to be longer. In addition, the more outcomes we seek to explain, the greater the problems of aggregating those outcomesand aggregation will be necessary to arrive at significant causal claims.

A straightforward way of selecting the outcome to explain is to identify the principal goals of an institution and to define those goals as dimensions over which behavioral or environmental outcomes vary. Such goals should be defined in terms of environmental problems that the institution is supposed to solve. This type of outcome is relatively easy to measure; it is closely related to problem solving; and it facilitates the analysis because an institution is more likely to have an observable and explainable effect in the area(s) it explicitly targets.

The principal goal of the institution to protect the stratospheric ozone layer is to reduce anthropogenic emissions of ozone depleting chemicals, such as CFCs. To achieve this goal, the institution aims at reducing the production of such chemicals. The dimension of variation is the production of ozone depleting chemicals. The outcome to be explained is variation in the produc-

50. Yarbrough and Yarbrough, "International Institutions and the New Economic of Organization," p. 253.

51. Geir Ulfstein, "The Barents Sea After the Cold War," paper presented at the annual meeting of the International Studies Association, Washington, D.C., 28 March-1 April 1994. 
tion of specific ozone depleting chemicals, or the entire class of such chemicals, over time, across countries, or other units of analysis. ${ }^{52}$ In measuring these outcomes, we need to be sensitive to the possibility that institutional goals change over time. The goal of the international whaling institution, for example, changed in 1982 from sustainable management of whales to the protection of whales (zero catches).

The identification and measurement of outcomes, as defined above, poses the following problems. First, dimensions of variation may be difficult to identify because the goals of an institution are ambiguous. This problem can only be resolved through careful study of treaty texts and other documents, interviews, and possibly disaggregation of ambiguous goals into several dimensions of variation.

Second, international environmental institutions can have more than one goal. In this case, the analyst may select the goal that is considered the most important according to environmental criteria or the perceptions of policymakers. Standardized interviews with experts or policymakers might support such a selection. Alternatively, the analyst can select several or all of the goals and aggregate the resulting variables into one or more dependent variables. If goals are contradictory, aggregation will of course be difficult. The International Tropical Timber Agreement aims at enhancing trade in tropical timber and improving sustainable forest management. ${ }^{53}$ Before 1982, the International Whaling Commission sought to regulate the utilization of whale resources and to conserve these resources. In both cases, the two goals have different end points. In the timber case, for example, optimal sustainable forest management is likely to be associated with a different extent of timber harvesting than the optimal level of timber trade. In such cases, each dimension should be measured and explained separately. The advantage of not aggregating these outcomes may be that it produces more cases for comparison. The analyst can investigate whether and why an institution has been more or less successful with regard to one goal than another.

Third, institutional goals are critical for identifying the institution as an environmental one. The boundary in this regard is often unclear. The goals of the Senegal River-basin institution, for example, are to expand hydroelectric power production and irrigation and to facilitate navigation through flood control..$^{54}$ They have little to do with environmental conservation in the traditional sense and more to do with resource management. In the case of fisheries, institutions are often regarded as environmental only when fish stocks

52. For an analysis of institutional effect in the ozone layer case, see Edward A. Parson, "Protecting the Ozone Layer," in Haas, Keohane, and Levy, Institutions for the Earth, pp. 27-73.

53. Kenton R. Miller, Walter V. Reid, and Charles V. Barber, "Deforestation and Species Loss," in Mathews, Preserving the Global Environment, pp. 78-111.

54. C. O. Okidi, "Environmental Stress and Conflicts in Africa: Case Studies of African International Drainage Basins," manuscript, School of Environmental Studies, Moi University, Eldoret, Kenya, 1992. 
crash. However, the problem here is one of explanation rather than definition and measurement of outcomes. Should we consider environmental institutions as a separate class of international institutions? Doing so is analytically useful only to the extent that it facilitates the comparison of different institutions of a given class by holding class-specific variables constant. Whether there are class-specific variables, for example high uncertainty, that make environmental institutions different from other institutions is an open question. Focusing on environmental institutions is usually done for normative or pragmatic rather than analytical reasons. ${ }^{55}$ From an analytical viewpoint, it might make more sense to compare the Senegal River institution with the Rhine regulations on chloride pollution rather than comparing the Rhine case with the ozone institution. The distinction along the lines of pure versus impure public goods, the number of actors involved, or the income of the actors might well turn out to be more fruitful than the distinction of environmental versus nonenvironmental institutions.

The above definition of outcomes is sufficient to conduct individual case studies. The effect of international institutions explains relative change against specific baselines toward or away from institutional goals. But for comparative research we need evaluative criteria that make changes in behavior or environmental outcomes comparable across cases. If we compare outcomes in the ozone case with outcomes in the area of international trade in toxic waste, we may, as a fictitious example, observe a worldwide decline by 50 percent in the production of CFCs and a 30 percent decline in illegal trade in toxic waste. ${ }^{56}$ In which case is there more environmental progress? The answer depends on the standards against which the outcome is assessed.

The most widely used standards are some notion of collective optimum (for example, the Pareto frontier), compliance, and the goal(s) of an institution. The third standard is (arguably) preferable to the other two. It is simpler to identify than a collective optimum, which scientists may disagree about and economists may find difficult to determine because costs and benefits are hard to measure. It is less susceptible to the endogeneity problem of compliance that was noted earlier. Broader goals determine the features of an institution to a lesser extent than specific institutional rules. In addition, when states set broader institutional goals, these goals are less likely to be lowest common denominator solutions than concrete international rules that have to be implemented within specific time frames. The principal weakness of this standard, from which the collective optimum and compliance standards also

55. For an attempt to distinguish cooperation on security and economic issues, which raises similar problems, see Charles Lipson, "International Cooperation in Economic and Security Affairs," World Politics 37 (October 1984), pp. 1-23.

56. For an analysis of international regulations on trade in toxic waste, see Christoph Hilz and John R. Ehrenfeld, "Transboundary Movements of Hazardous Wastes: A Comparative Analysis of Policy Options to Control the International Waste Trade," International Environmental Affairs 3 (Winter 1991), pp. 26-63. 
suffer, is that it does not take into account the relative importance of individual institutions. A 50 percent change toward the goals specified in the Framework Convention on Global Climate Change may be vastly more important from an overall environmental perspective than making the Rhine habitable for salmon by the year 2000-the goal of the Rhine Action Program.

In summary, the outcome to be explained in terms of the effect of international institutions can be defined as goal attainment: that is, the difference (over time or across cases) between actor behavior or the state of the natural environment along dimensions defined by institutional goals and end points defined by institutional goals. The validity of this variable derives from its close relation to the notion of problem solving. Due to the measurement problems discussed above, the reliability of the collected data will normally be less than perfect, but it can be enhanced by using ordinal-scaled scores with only a few categories (e.g., low, medium, and high goal attainment).

\section{Measuring the effect and effectiveness of institutions}

The extent to which the existence or operation of the institution per se accounts for variation in goal attainment provides the measure of the effect of an institution on goal attainment. The measurement of institutional effect is more difficult than the measurement of goal attainment because it involves an element of causal analysis. An institution has an effect to the degree that we can reject the null hypothesis, which holds that goal attainment would, ceteris paribus, not be different in the absence of the institution.

To give a simple example, assume that we observe a 25 percent reduction across the board in the major pollution parameters of the Rhine, whereas a 50 percent reduction is the goal of the institution regulating pollution of the Rhine. Hence the degree of goal attainment is 50 percent (or medium). To what degree can this progress be attributed to the existence or operation of the Rhine institution? Let us assume that, based on the study of various competing explanations for this progress, we find that international regulations account for half of the progress. In this case, we may conclude that the Rhine riparians can rightly claim a medium degree of success in terms of achieving the environmental goal and that international regulations account for half of this progress. The other half may be explained, for example, by changes in the production technology of chemical firms along the Rhine that would have occurred irrespective of international regulations.

How can we arrive at such a result? As the above example suggests, the key is to sort out the effects of exogenous (noninstitutional) and endogenous (institutional) variables on goal attainment. The cause of variation in goal attainment may not be environmental institutions but instead the variation of preferences and power structures, which can result from political and economic changes, changes in the natural environment, technological innovation, population growth, positive or negative spillovers from other international or national 
institutions, and other variables. Controlling for the effect of preferences and power structures on the relationship between institutions and goal attainment is crucial not only for obtaining valid and reliable data on institutional effect but also because it addresses the wider theoretical debate about the role of institutions in international politics.

The task will be comparatively easy if we conduct a case study where power structures and preferences remain constant over time and an institution comes into being along the way or changes its features. In this case, we can argue that the institution is largely the cause of the variation in goal attainment we may observe. Mitchell, for example, shows that compliance with international regulations on intentional oil pollution of the sea increased after these regulations changed. Earlier regulations had required tanker operators to limit their oil discharges, whereas the new regulations required the installation of specific pollution reduction equipment on tankers. Mitchell notes that the actors and types of activity involved, the concentration of costs and benefits of regulations across actors, and the binding nature and legitimacy of the agreements remained constant over time. Because the new regulations were more expensive for tanker operators than the old regulations, one would expect lower levels of compliance. The observation that the opposite occurred is attributed to the fact that the new regulations have increased transparency, reduced the implementation costs of governments, and changed the incentives of shipping companies and crews by enabling better enforcement of the rules. ${ }^{57}$

In cases where preferences and power structures change over time or across cases, the measurement of institutional effect will be more difficult. However, we can control for the influence of preferences and power structures within a game-theoretic framework. This approach suffers from well-known problems, such as identifying ex ante preferences. ${ }^{58}$ To avoid this problem, we can infer preferences from data on environmental vulnerability and the costs of particular environmental regulations. ${ }^{59}$ Even less than perfect results can direct our attention to critical situations where institutions could make a difference or where they are likely to have little effect.

In assurance games, for example, two or more equilibria are possible. As a result, governments may encounter great difficulties in trying to settle on one equilibrium. But once an equilibrium is reached, no actor has an incentive to make a change in behavior. In this case, successful cooperation does not require institutions that have a large monitoring and enforcement capacity. The principal problem is to achieve cooperation, not to sustain it. This implies

57. Ronald B. Mitchell, "Regime Design Matters: Intentional Oil Pollution and Treaty Compliance," International Organization 48 (Summer 1994), pp. 425-58.

58. See, for example, James E. Alt and Kenneth A. Shepsle, eds., Perspectives on Positive Political Economy (Cambridge: Cambridge University Press, 1990).

59. For an innovative approach to measuring ex ante preferences, which is based on indicators of environmental vulnerability and costs of environmental regulation, see Detlef Sprinz and Tapai Vaahtoranta, "The Interest-based Explanation of International Environmental Policy," International Organization 48 (Winter 1994), pp. 77-105. 
that, even if we observe a correlation between the existence or operation of an institution and goal attainment, the causal effect of the institution is likely to be small, provided that the structure of the game has remained constant. The more recent phase of the ozone case may be regarded as an assurance game. As it became clear that an international ban on CFCs would be adopted, the principal CFC producers began to consider the ban as beneficial because it would create a large market for more profitable CFC substitutes. Hence, they lost any incentive to cheat on such a ban.

In prisoners' dilemma games, actors have a strong incentive to defect clandestinely. Under these circumstances, institutions that install strategies of strict reciprocity and have monitoring and enforcement procedures will facilitate cooperation. ${ }^{60}$ If, under these conditions, we observe a correlation between changes in the monitoring, enforcement, or reciprocity mechanisms of an institution and goal attainment, we have reason to suspect a causal relationship between the institution and goal attainment. The oil pollution case discussed above is such an example. The technical equipment to be installed on tankers is expensive. Consequently, those actors who manage to circumvent the regulations can gain a competitive advantage.

In zero-sum games and situations of harmony, institutions are likely to play a marginal role or will not be established in the first place. In zero-sum games, cooperation achieves no joint gains. A stable cooperative equilibrium defines situations of harmony: no actor has an incentive to defect, no matter what the other actors do. For example, the Dutch city of Rotterdam concluded agreements with various chemical firms along the Rhine in Germany and Switzerland. The Dutch hailed the ensuing emission reductions by these firms as a success. But critics have argued that the chemical companies concerned were planning to cut their pollution anyhow and that the agreements with Rotterdam were concluded merely for public relations purposes. ${ }^{61}$

In controlling the impact of power structures, we have to assess the degree to which we should attribute variation in goal attainment to the willingness of powerful states to deploy positive or negative incentives to modify the behavior of other actors in a particular direction. Scholars have often explained variation of collective outcomes in international trade and finance in these terms. ${ }^{62}$ In environmental politics, it has been widely argued that the blanket moratorium adopted by the International Whaling Commission in 1982 has achieved its goal largely because the United States threatened sanctions against violators of the moratorium..$^{63}$

60. Duncan Snidal, "Coordination Versus Prisoner's Dilemma: Implications for International Cooperation and Regimes," American Political Science Review 74 (December 1985), pp. 923-42.

61. Personal interview with Walter Jülich, Internationale Arbeitsgemeinschaft der Wasserwerke im Rheineinzugsgebiet (International Association of Waterworks in the Rhine Basin), Amsterdam, December 1993.

62. Keohane, After Hegemony.

63. Steinar Andresen, "Science and Politics in the International Management of Whales," Marine Policy 13 (April 1989), pp. 99-117. 
The method we use to assess the effect of institutions is a secondary issue. It will depend largely on the available data. If valid and reliable hard data on goal attainment, institutions, and control variables are available and if we have enough observations, we can use statistical analysis. We may, for example, define institutions or their features as a dummy variable (an institution or a feature exists or does not exist) and use multivariate analysis to assess the effect of institutions on goal attainment. In such an analysis, we control exogenous variables by including them in multiple regression models or time-series analysis. Thomas Widmer, for example, uses the Box-Tiao method to examine the effect of Swiss governmental regulations on sulfur dioxide emissions. ${ }^{64}$ Christopher Lenhardt evaluates the effect of the General Agreement on Tariffs and Trade (GATT) on developing country trade, employing a more simple statistical technique. ${ }^{65}$ Dieter Ruloff and Gerald Schneider use time-series analysis to assess the effect of various political events on conflict and cooperation between the two superpowers. ${ }^{66}$ Glenn Stevenson applies sophisticated econometric methods to examine whether Swiss alpine grazing lands are more successfully managed under common property or under private property regimes. ${ }^{67}$

Analysts have rarely used statistical methods to study the effect of institutions in international environmental politics. These methods require a larger number of observations, which limits the cases to which they may be applied. Even Stevenson's analysis, which compares 245 grazing areas, quickly produces insignificant results as he increases the number of control variables. In the end, he is unable to offer even simple advice to Swiss farmers on what form of property rights would be more beneficial to them. ${ }^{68}$ The number of international regulations over time and across cases tends to be small, and valid and reliable data are often difficult to find. It would seem, however, that we could apply statistical methods in cases where environmental regulations have a long history. Based on a qualitative analysis, I argue elsewhere that the cause of the modest chloride reductions of the Rhine riparians since the late 1980s is the decline of potash and coal mines and of soda factories along the river, rather than the international regulation of chloride emissions. Time-series analysis of

64. Thomas Widmer, Evaluation von Massnahmen zur Luftreinhaltepolitik in der Schweiz (Evaluation of clean-air policy in Switzerland) (Chur, Switzerland: Verlag Rüegger, 1991). The Box-Tiao method was proposed by George E. P. Box and George C. Tiao, "Intervention Analysis with Applications to Economic and Environmental Problems," Journal of the American Statistical Association 70 (March 1975), pp. 70-79.

65. W. Christopher Lenhardt, "International Trade and Measuring the GATT Regime Effect on Developing Country Trade," paper presented at the annual convention of the International Studies Association, Acapulco, Mexico, 23-27 March 1993.

66. Dieter Ruloff and Gerald Schneider, "Gorby, Grit, or Rambo: A Quantitative Appraisal of the End of the Cold War," paper prepared for the annual convention of the International Studies Association, Atlanta, Georgia, 31 March-4 April 1992.

67. Glenn G. Stevenson, Common Property Economics: A General Theory and Land Use Applications (Cambridge: Cambridge University Press, 1991).

68. Ibid. 
chloride emissions (data back to 1885 are available) could produce similar, perhaps even more precise, results. ${ }^{69}$

For qualitative assessments of institutional effect, we rely on process tracing or thick description. This means developing detailed narrative accounts that describe the causal chains leading from institutions to goal attainment and focus in particular on critical decision-making points. Counterfactual analysis, which is essentially a thought experiment, ${ }^{70}$ enhances causal claims that are made in this regard. Counterfactual analysis explores what goal attainment might have looked like in the absence of a given institution.

If we can demonstrate, through statistical analysis or qualitative methods, that preferences or power structures that are independent of an international institution cause variation in goal attainment, the institution has no effect. In the stratospheric ozone case, for example, the institution has no effect if we can prove that CFC producers have cut their production only because they expected higher profits from the sale of CFC substitutes than from the sale of CFCs, irrespective of what happened in terms of international regulation. We might also argue, however, that the regulatory effort, spurred by the discovery of the ozone hole, changed the incentives of CFC producers and caused them to invest in research on CFC substitutes. This research led to CFC substitutes, whose market value is higher. If there had been no international regulatory effort, CFC substitutes would have come on the market much later and CFC production would have diminished at a lower rate. ${ }^{71}$ If we can disconfirm the null hypothesis in part through such an argument, we must try to assess the relative weight of institutional and noninstitutional explanatory variables.

The ozone example suggests that measurements of institutional effect will rarely be clear cut and totally reliable, because behavior and environmental outcomes are often due to multiple causes and because we cannot control history as we do laboratory events. Such measurements will always contain an element of judgment. Independent evaluations of the same institution along the lines proposed here and an intensified debate about critical data among researchers will, therefore, be important. An additional strategy to enhance the reliability of institutional effect scores is to submit them to policymakers and experts for independent review.

Ideally, the assessment of institutional effect will produce ordinal-scaled scores indicating the degree to which institutions affect goal attainment over time or across cases. The data on goal attainment and institutional effect can

69. Thomas Bernauer, "International Financing of Environmental Protection."

70. See James D. Fearon, "Counterfactuals and Hypothesis Testing in Political Science," World Politics 43 (January 1991), pp. 169-95; and David Dessler, "Beyond Correlations: Toward a Causal Theory of War," International Studies Quarterly 35 (September 1991), pp. 337-55. For a comprehensive treatment of qualitative methods, see Gary King, Robert O. Keohane, and Sidney Verba, Designing Social Inquiry: Scientific Inference in Qualitative Research (Princeton, N.J.: Princeton University Press, 1994).

71. For an analysis of the ozone case, see Benedick, Ozone Diplomacy; and Parson, "Protecting the Ozone Layer." 
then be used to form a score of institutional effectiveness. The most effective institutions will be those where both the degree of goal attainment and the degree of institutional effect are high. The least successful institutions will be those where goal attainment and institutional effect are low. Such an index will be comparable over time and across cases. It might indicate, for example, that the institution that oversees long-range transboundary air pollution in Europe has, in the past few years, been more effective than the international whaling institution was in the $1960 \mathrm{~s}$.

\section{Institutional design and the effectiveness of institutions}

The final step in the analysis consists of examining the implications of institutional design for institutional effectiveness. In the preceding section, we focused on the extent to which variation in goal attainment can be explained by the existence or operation of institutions. Now we pose questions about the degree to which particular features of institutions are responsible for variation in the performance of these institutions.

As noted earlier, political scientists and others have put forth a plethora of propositions as to which types of institutions are likely to be more effective. To render meaningful quantitative or qualitative inference about the consequences of institutional design possible, we must focus on a small number of institutional design variables. From a theoretical viewpoint, this reduction in the number of explanatory variables should aim at reducing the number of ad hoc propositions and focus on variables we can integrate into a coherent theoretical argument. This approach may seem somewhat less attractive to the policymaker than to the social scientist interested in systematic theory building. However, if we cannot determine the causal relationships correctly, we cannot offer good advice to policymakers. The methodology for examining the impact of institutional design on institutional effectiveness is similar to that used in the preceding step. Depending on the available data, our assessment may rely on statistical analysis or on process tracing or thick description.

The focus on institutional design variables that we derive from rationalchoice theory is likely to produce relatively coherent explanations. A large body of rational-choice literature in political science and economics explains how individual choices are aggregated into collective decisions through voting rules or other mechanisms and how variables such as the extent and distribution of information on actor intentions and behavior influence the possibilities of successful cooperation. ${ }^{72}$ Decision rules, membership conditions, and the compliance system of institutions are among the more important institutional

72. See, for example, Michael Taylor, The Possibility of Cooperation (Cambridge: Cambridge University Press, 1987); Todd Sandler, Collective Action: Theory and Applications (Ann Arbor: The University of Michigan Press, 1992); Peter C. Ordeshook, Game Theory and Political Theory: An Introduction (New York: Cambridge University Press, 1986); and Kydd and Snidal, "Progress in Game-Theoretical Analysis of International Regimes." 
design dimensions. They influence the effectiveness of institutions by shaping the functions that these institutions perform.

We could hypothesize, for example, that majority voting rules combined with open membership are likely to make an institution more effective. Majority voting forces states to reveal their preferences. Thus, it exposes environmental laggards more clearly. It allows more progressive states and nongovernmental organizations (NGOs) to set the goals and push the laggards forward through specifically targeted punishments or rewards. Moreover, even if the more progressive states move ahead while overruled states drag their feet, the overall outcome in terms of goal attainment may often be superior to a lowest common denominator approach.

We can make such an argument for the international whaling institution. Because this institution is open to any state, advocates of a total ban on whaling were able to bring many nonwhaling nations into the International Whaling Commission. Most of the newcomers supported a total ban. The majority voting rule of the commission thus permitted the strengthened antiwhaling coalition to overrule laggard states such as Japan and Norway and adopt a blanket moratorium in 1982 with a two-thirds majority. ${ }^{73}$ Whether this change has enhanced the effectiveness of the institution requires further study. Another case where variation in voting rules may account for institutional effectiveness is the European Community and its successor, the EU. In this case, we could examine whether the greater frequency of majority decision making since the adoption of the Maastricht treaty has changed the effectiveness of EU environmental regulations. ${ }^{74}$ The explanatory weight of voting rules might be smaller, however, if we conduct larger-scale comparative work, because most environmental institutions operate with the consensus rule.

Another hypothesis is that those institutions whose design generates a higher extent and intensity of information flows (monitoring) at low cost are likely to be more effective under prisoners' dilemma conditions. Monitoring and reporting procedures of the International Labor Office, the International Monetary Fund, or the GATT (now the World Trade Organization) are interesting cases where the design of the compliance system is likely to have implications for the effectiveness of the institution..$^{75}$ Mitchell's study on intentional oil pollution argues that changes in the design of the compliance system increased compliance (the same would seem to hold for effectiveness)

73. See M. J. Peterson, "Whalers, Cetologists, Environmentalists, and the International Management of Whaling"; and Asgrimsson, "Developments Leading to the 1982 Decision of the International Whaling Commission for a Zero Catch Quota 1986-90."

74. For an analysis of European Community/Union environmental policy from an institutionalist perspective, see Philipp M. Hildebrand, "The European Community's Environmental Policy, 1957-'1992': From Incidental Measures to an International Regime," in David Judge, ed., A Green Dimension for the European Community: Political Issues and Processes (London: Frank Cass, 1993).

75. See, for example, Peter H. Sand, Lessons Leamed in Global Environmental Governance; Chayes and Chayes, "On Compliance"; and Dan Kovenock and Marie Thursby, "GATT, Dispute Settlement, and Cooperation," Economics and Politics 4 (July 1992), pp. 151-70. 
because they increased transparency and reduced the costs of monitoring and enforcement. The generalizable institutional design lesson involved is that regulations that give practical ability and legal authority to implement regulations to those actors with the greatest incentive to comply and monitor and enforce regulations are likely to be more effective. ${ }^{76}$

These two examples offer propositions we need to test further, and the list is far from complete. Additional propositions worth analysis might relate to the nature of international secretariats, the organization of scientific input, or the scope of the institutional agenda. ${ }^{77}$ Students of domestic institutions have carried out the most systematic research on the consequences of institutional design for the management of natural resources and environmental protection. Many of the propositions that this research has generated-for example, that institutional effectiveness increases with the congruence of rules and local conditions, the access to low-cost conflict resolution mechanisms, or the clear definition of property rights-appear compatible with a rational-choice argument. Keohane, McGinnis, and Ostrom have explored how some of these propositions could be translated to the international level. ${ }^{78}$ But so far no analysts have undertaken a systematic empirical assessment. Hence the most interesting and potentially rewarding research on the effect of international environmental institutions lies in the future.

\section{Conclusion}

We have made substantial progress in understanding the conditions under which states are able to establish international institutions to protect the environment. We have been less successful in explaining the performance of these institutions once they have been established. Many analysts of international politics believe that the existence or operation of international institutions, and good institutional design in particular, can contribute to progress in environmental protection. Others contend that, as long as there is no environmental leviathan, the distribution of power and the interests of key actors account for collective outcomes in international relations. Systematic empirical research into the effect of international environmental institutions contributes to international relations theory by assessing the two competing claims. It may also generate practical advice to policymakers by evaluating whether decision makers, NGOs, or other actors should preferably try to manipulate power structures and preferences to achieve their goals, or whether they can also facilitate environmental protection by improving the design of international institutions and, if so, how.

76. Mitchell, "Regime Design Matters."

77. A preliminary discussion of such design dimensions can be found in Wettestad, Institutional Design and the Effectiveness of International Environmental Regimes.

78. Keohane, McGinnis, and Ostrom, Proceedings of a Conference on Linking Local and Global Commons. 
Current research on the effect of international environmental institutions suffers from two deficiencies. Dependent variables (institutional effect, effectiveness, efficiency, etc.) and explanatory variables (institutions and their features) are ill-defined, contested, and rarely married to a coherent theory. Second, analysts have focused on whether the existence or operation of institutions per se has an effect on actor behavior and other outcomes. Virtually no work has offered generalizable and empirically substantiated knowledge regarding which institutional design variables are critical to the success or failure of institutions under specific conditions.

This article has outlined a positive research strategy that may serve as a basis for more systematic and policy-relevant research on the effect of international environmental institutions. The proposed research strategy consists of three steps. First, we measure the outcomes to be explained in terms of goal attainment, defined as the difference between actor behavior or the state of the natural environment on dimensions defined by institutional goals and end points defined by institutional goals. Second, we assess the effect of an institution in terms of the extent to which the institution has, ceteris paribus, contributed to variation in goal attainment. We transform these two variables into a score of institutional effectiveness. Third, we analyze the relationship between institutional effectiveness and particular institutional design variables, for example decision rules, membership conditions, or the compliance system.

This research strategy is rather demanding, and we may have to modify parts of it as empirical research continues. Moreover, I have conceptualized explanatory and dependent variables quite narrowly to keep the task manageable. This approach may evoke criticism from analysts who have one foot in the policy world. Unfortunately, however, we cannot offer good policy advice before we clearly understand the causal relationships between institutional design options and the performance of institutions. So far, we have not reached this point.

The proposed research strategy provides a starting point for more rigorous and comparable case studies. These case studies are required to sharpen the research design and generate new hypotheses. The strategy can also serve as a starting point for larger-scale comparative research. Such research is indispensable to arrive at generalizable propositions about necessary or sufficient conditions for the effectiveness of international institutions. The United Nations Conference on Environment and Development in 1992 and the scholarly activity it has spurred have generated large amounts of data on international environmental institutions, the associated behavior of governments and other actors, and changes in the natural environment. And more data are yet to come, not least from the expanding activities of international organizations and NGOs. If we can shape our analytical concepts, propositions, and research strategies properly, we could make an important contribution to international relations theory and also facilitate the protection of the earth's environment. 